\title{
A REVIEW OF THE BIOGENESIS OF IRON NANOPARTICLES USING MICROORGANIMS AND THEIR APPLICATIONS
}

\author{
Lilia Anghel ${ }^{a^{*}}$, Gheorghe Duca ${ }^{\mathrm{b}}$ \\ anstitute of Chemistry of the Academy of Science of Moldova, 3, Academiei str., Chisinau MD-2028, Republic of Moldova \\ ${ }^{b}$ Academy of Science of Moldova, 1, Stefan cel Mare Blvd., Chisinau MD-2001, Republic of Moldova \\ *e-mail: anghel.lilia@gmail.com
}

\begin{abstract}
Iron-based nanoparticles have gained a lot of attention due to their properties which offer a broad range of biomedical and industrial applications. Traditional methods of synthesis of iron nanoparticles strongly influence their properties and limit their applicability. Recently, there has been a growing interest in the development of biological routes of syntheses of iron nanoparticles as the resulting particles have structural characteristics required by biomedical field. The mechanism for the synthesis of iron-based nanoparticles by microorganisms and its current limitation are presented.
\end{abstract}

Keywords: nanoparticles, iron, microorganisms, biological synthesis, biomedical applications.

\section{Introduction}

Iron is one of the most abundant metals of the Earth's crust. It is found mostly in different forms of iron oxide widespread in nature and readily synthesized in the laboratory [1]. Iron based nanoparticles have been studied extensively because of their wide range of applications including magnetic recording media, environmental remediation, and biomedicines [2-7]. The physical and chemical properties of iron nanoparticles are mainly determined by their size, shape, composition, crystallinity and structure [8-10]. Therefore, in almost all applications the preparation method of the nanoparticles is one of the most important factors that will influence their properties and potential applicability. Various methods of synthesis have been reported including chemical reduction, thermal decomposition, hydrothermal synthesis, microemulsion, and decomposition by ultrasonic treatment, electrochemical generation [11-18]. Nonetheless, development of pathways for nanoparticles production with a better control over the particle size, monodispersity, morphology, purity, quantity and quality by employing economical process is still of a great challenge [19]. One of the options to overcome this challenge is to use microorganisms to synthesize nanoparticles.

Biological routes of synthesis are preferred mainly due to their overcoming advantages over other methods. Advantages such as reaction conditions benign for environment, adequate range of material sources present and good nature of reduction takes place to form nanoparticles. The time for completion of the reaction, which is an obvious advantage of the biosynthetic procedures compared to the chemical methods [20]. The biogenic approach is also sustained by the fact that most of the microorganisms inhabit ambient conditions of varying temperature, $\mathrm{pH}$, and pressure [21]. It was found that biosynthesized nanoparticles due to their specific properties excel those obtained by means of physical or chemical methods [22]. Biogenic nanoparticles have a higher catalytic reactivity, greater specific surface area, and an improved contact between the enzyme and metal salt in question due to the bacterial cell wall network [21, 23, 24].

Various methods have been developed for the biosynthesis of iron nanoparticles [25]. According to the location were nanoparticles are formed, these processes are classified into intracellular [26] and extracellular [27,28] synthesis. Biogenic processes are important in the formation of these nanoparticles, in general terms they are known as biomineralization. The mechanism of nanoparticles formation in microorganisms is complicated because of implication of different metabolic systems, but generally it can be described as a two-step process. The first step is the uptake of the organic or inorganic metal species, both soluble and insoluble, by physic-chemical mechanism such as adsorption. Metal ions are adsorbed onto the surface of cells by interactions between metals and functional groups displayed on the surface of cells. The second step is a redox-mediated mechanism which involves the participation of membrane proteins responsible for acquisition of a specific metal ion. These processes end with transportation of ions trough cell's membrane, their deposition and intracellular nanoparticles formation.

Hereby, we attempt to present the current perspectives in the research field focused on biological synthesis of iron-based nanoparticles. This is followed by concise discussions of the nanoparticles properties arising from the size/shape and monodispersity of particles. Next, current applications of iron nanoparticles in the technological and biomedical fields are presented.

\section{Biological synthesis of iron-based nanoparticles}

Iron is used by microorganism to build enzymes that catalyze biochemical reactions within the cell [29]. Yet, when the cellular concentration of iron becomes greater it causes oxygen to react destructively with many 
biomolecules. As a result, microorganisms have evolved mechanism for buffering high concentrations. When a microorganism takes in more metal than it needs, it stores the excess in either protein storages or simple nanoparticles extracellularly or intracellularly. These storages are accessed by microorganisms when there is not enough iron in their environment.

The exact mechanism for the biosynthesis of metal nanoparticles using microorganisms has not been established yet. One of the reasons is that microorganisms react differently with metal ions and also the existence of different metabolic processes which contribute to the synthesis of nanoparticles. In addition, the mechanism for intracellular and extracellular synthesis of nanoparticles is different for various microorganisms. A major factor which influences the intracellular synthesis of nanoparticles is the chemical composition of the cell wall of the microorganism [30]. The negatively charged cell wall will interact electrostatically with the positively charged metal ions. The proteins present within the cell wall reduce the metal ions to nanoparticles, and finally the smaller sized nanoparticles get diffused of through the cell wall. As mentioned earlier, biological synthesis of metal nanoparticles is a two-step process, wherein biosorption of metal ions is followed by bio-reduction to metal nanoparticles extracellularly or intracellularly.

\section{Biosorption processes}

Biosorption has been defined as a multitude of metabolically independent processes based on passive uptake of ions, which occur in non-living biomass. It has been attested that biosorption processes comprise different mechanisms and not just one, depending on the ionic species used, the type of biomass and how it is pretreated [31-33]. Furthermore, there are other factors affecting the biosorption of metal species by biomass that should be considered, such as:

- cell size and morphology;

- $\mathrm{pH}$ of the external media;

- cation and anion concentration in the external media;

- metal speciation;

- temperature;

- physiology of the biomass [34].

It has been established that metal sequestration is achieved through the following processes: physical sorption, ion exchange, chelation; and ion fixation in inter- and intrafibrillar capillaries and spaces of the structural polysaccharide matrix as a result of the concentration gradient and diffusion through cell walls [35-37]. Cells biomass has a very complicated chemical composition being composed of various active groups which participate in the binding of chemical substances or ions, contributing to their entrapment in the biomass solid substance [38]. According to Volesky [39-41], there are several chemical groups that could contribute to the metals acquisition by biomass: acetamido groups of chitin, structural polysaccharides of fungi, amino and phosphate groups in nucleic acids, amino, amido, sulfhydryl, and carboxyl groups in proteins, hydroxyls in polysaccharides, and mainly carboxyls and sulfates in the polysaccharides of marine algae. However, the presence of some functional group is not the main factor which contributes to the biosorption processes [42].

\section{Biomineralization}

The second step in nanoparticles formulation consists of processes of metabolically mediated reduction, transport and deposition of chemical specie. The initial stages of iron nucleation require the participation of the protein / enzyme which is also responsible for iron transport within the cell of the microorganism [43,44]. At this stage, depending on the microorganism metabolic pathways there are several proteins able to participate: transferrin, lactoferrin, iron transport multicopper oxidase (Fet3p). Graphical representations of these proteins are presented in Figure 1. The high-resolution crystallographic structures had Protein Data Bank [45] codes of 1ZPU (iron transport multicopper oxidase structure file) [46], 3QYT (transferrin structure file) [47], 1B0L (lactoferrin structure file) [48].

It was shown that the inner surface of the protein shell is a source of ligands which are responsible for partial coordination of iron and with a coordination degree available for mineral phase anions withal. This specific coordination gives start to the biomineralization process resulting in the formation of ferrihydrite core which serves as precursor for iron nanoparticles [49].

The overall reaction of the iron interaction with ferrioxidaze protein confirmed by Chasteen 1999 [50] is postulated as follows:

$$
\text { Protein }+2 \mathrm{Fe}^{2+}+\mathrm{O}_{2}+3 \mathrm{H}_{2} \mathrm{O} \rightarrow \text { Protein- }\left[\mathrm{Fe}_{2} \mathrm{O}(\mathrm{OH})_{2}\right]+\mathrm{H}_{2} \mathrm{O}_{2}+2 \mathrm{H}^{+}
$$

According to Chasteen 1999 [50] iron is transferred from the ferroxidase complex to the core nucleation sites through the following reaction:

$$
\text { Protein- }\left[\mathrm{Fe}_{2} \mathrm{O}(\mathrm{OH})_{2}\right]+\mathrm{H}_{2} \mathrm{O} \rightarrow \text { Protein }+2 \mathrm{FeOOH}_{\text {core }}+2 \mathrm{H}^{+} \text {. }
$$




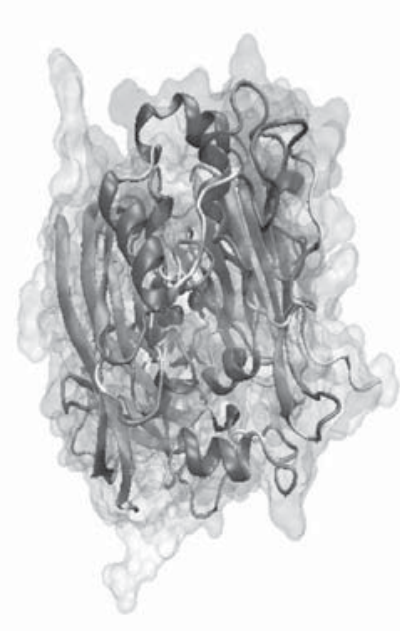

(a)

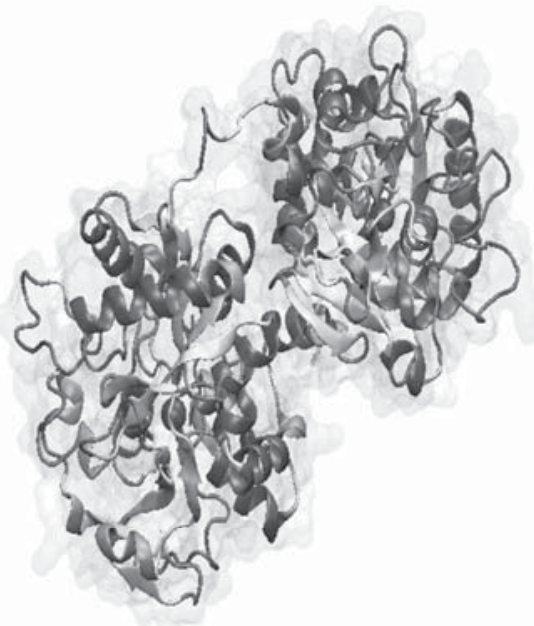

(b)

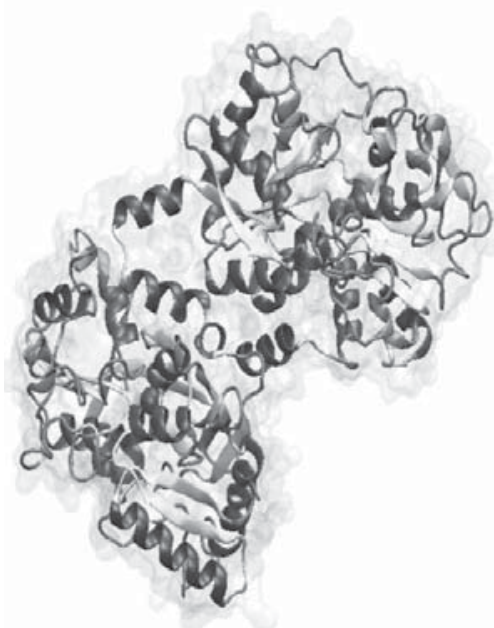

(c)

Figure 1. Ribbon representation of iron transport multicopper oxidase (a), transferrin protein (b) and lactoferrin protein (c) based on the coordinates from Protein Data Bank. The images were obtained using graphical interface software Visual Molecular Dynamics [51].

A hypothetic mechanism of iron uptake by Gram-negative bacteria and yeast cell is presented in Figure 2 . According to the literature sources [49], in case of Gram-negative bacteria, bounded iron is transported to specific membrane receptors which are responsible for unloading $\mathrm{Fe}^{3+}$ ions from lactoferrin, transferrin, haem or haem containing molecules, or $\mathrm{Fe}^{3+}$-siderophores synthesized by bacteria and fungi. It is also mentioned that there are three proteins inserted in the cytoplasmic membrane and coupled to the receptors are TonB, ExbB and ExbD. The last ones being responsible for forwarding the energy delivered by the proton-motive force of the cytoplasmic membrane for active transport across the outer membrane. Thus, periplasmic binding proteins deliver $\mathrm{Fe}^{3+}$ and $\mathrm{Fe}^{3+}$ siderophores to one or two integral cytoplasmic membrane proteins, which translocate them into the cytoplasmat the expense of ATP provided by ATPases associated with the inside of the cytoplasmic membrane. A similar mechanism of the transport system is attributed to Gram-positive bacteria with the exception consisting in the lack of protein receptors and of TonB, ExbB and ExbD proteins. $\mathrm{Fe}^{2+}$ transport system differs from the one of $\mathrm{Fe}^{3+}$, it is accomplished under anaerobic conditions and through the Feo system. Yeast cells have a much simpler mechanism for iron acquisition. This mechanism involves the participation of a protein, Fet3p, which is responsible for mediation of iron oxidation, resulting in plasma membrane iron transport through the permease Ftrlp, leading to iron deposition and formulation of nanocrystals.
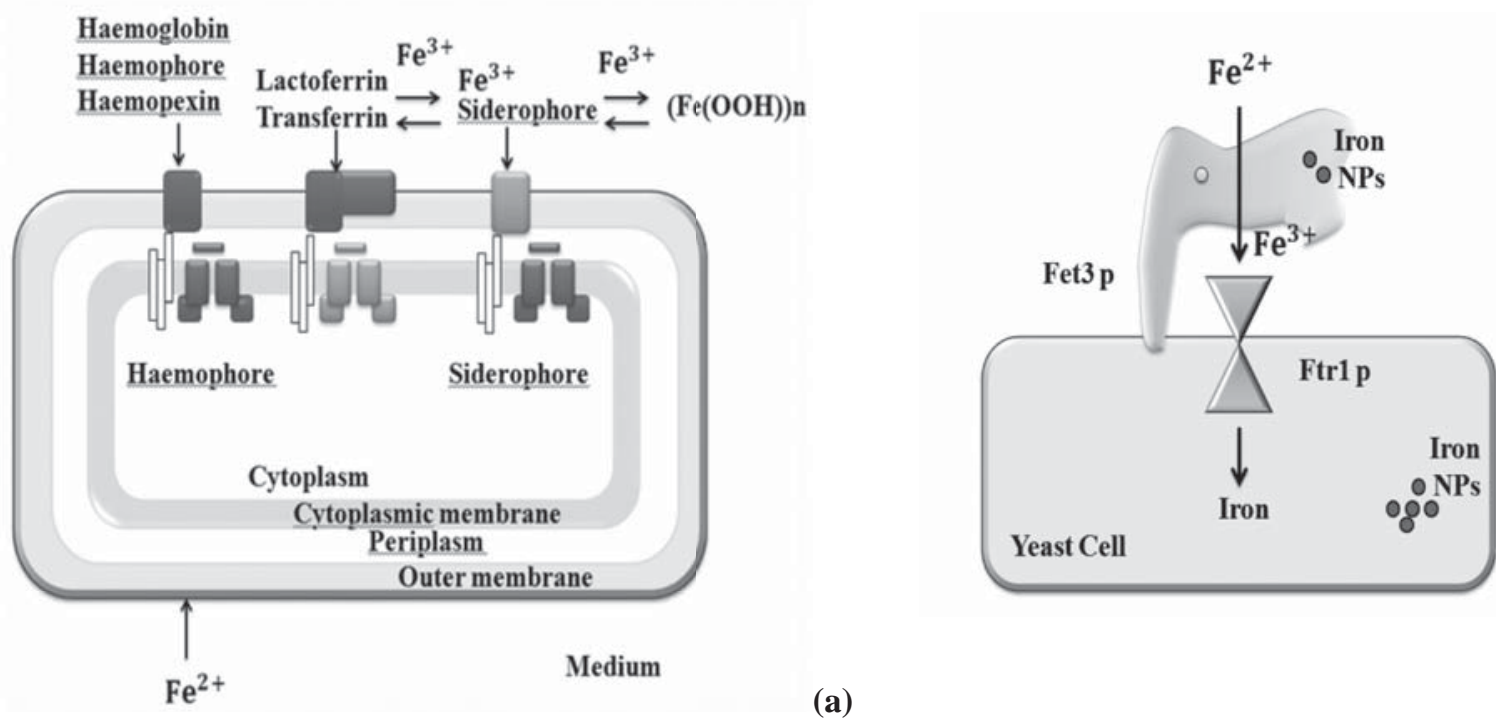

Figure 2. Comparison iron uptake mechanism and nanoparticles formulation within the cell of Gram-negative bacteria (a) and yeast (b), as stated by Crichton 2001 [49]. 
Table 1.

Biosynthesis of iron nanoparticles by different microorganisms.

\begin{tabular}{|c|c|c|c|c|c|}
\hline Microorganisms & Product & Size & Shape & Location & References \\
\hline Recombinant AMB-1 & magnetite & $20 \mathrm{~nm}$ & $\begin{array}{l}\text { Octahedral, cubo- } \\
\text { octahedral }\end{array}$ & intracellular & {$[52]$} \\
\hline $\begin{array}{l}\text { Magnetotactic } \\
\text { bacteria }\end{array}$ & $\begin{array}{c}\text { Magnetite } \\
\left(\mathrm{Fe}_{3} \mathrm{O}_{4}\right) \text { and } \\
\text { Greigite } \mathrm{Fe}_{3} \mathrm{~S}_{4}\end{array}$ & $32-43 n m$ & Cubic & intracellular & {$[53]$} \\
\hline Yeast cells & $\begin{array}{l}\text { Iron phosphate } \\
\qquad\left(\mathrm{FePO}_{4}\right)\end{array}$ & $50-200 \mathrm{~nm}$ & $\begin{array}{c}\text { Spherical } \\
\text { aggregations }\end{array}$ & extracellular & {$[54]$} \\
\hline HSMV-1 & magnetite & $<45 \mathrm{~nm}$ & $\begin{array}{c}\text { Bullet or flat-top } \\
\text { shaped }\end{array}$ & intracellular & {$[55]$} \\
\hline Sargassum muticum & magnetite & $18 \pm 4 \mathrm{~nm}$ & Cubic & extracellular & {$[56]$} \\
\hline $\begin{array}{c}\text { BoFeN1 } \\
\text { Acidovorax sp. }\end{array}$ & Iron phosphate & $\begin{array}{l}100 \pm 25 \mathrm{~nm} \\
40 \mathrm{~nm}\end{array}$ & $\begin{array}{l}\text { Globular, } \\
\text { flat-shaped }\end{array}$ & $\begin{array}{l}\text { extracellular/ } \\
\text { intracellular }\end{array}$ & {$[57]$} \\
\hline $\begin{array}{l}\text { Shewanella } \\
\text { oneidensis }\end{array}$ & magnetite & $40-50 \mathrm{~nm}$ & $\begin{array}{l}\text { Cubic, } \\
\text { rhombic }\end{array}$ & extracellular & {$[58]$} \\
\hline $\begin{array}{l}\text { Desulfovibrio } \\
\text { magneticus }\end{array}$ & $\begin{array}{l}\text { Magnetite, } \\
\text { hematite }\end{array}$ & $\begin{array}{l}40 \mathrm{~nm} \\
5-10 \mathrm{~nm}\end{array}$ & Elongated & $\begin{array}{l}\text { intracellular/ } \\
\text { extracellular }\end{array}$ & [59] \\
\hline QH-2 & Magnetite & $58 \pm 20 \mathrm{~nm}$ & not available & intracellular & {$[60]$} \\
\hline $\begin{array}{l}\text { Aspergellius } \\
\text { fumigates }\end{array}$ & Magnetite & $42.40 \mathrm{~nm}$ & powder & not available & {$[61]$} \\
\hline $\begin{array}{l}\text { Chaetomium } \\
\text { globusum }\end{array}$ & magnetite & $25.30 \mathrm{~nm}$ & powder & not available & {$[61]$} \\
\hline $\begin{array}{l}\text { Curvularia } \\
\quad \text { lunata }\end{array}$ & magnetite & $20.80 \mathrm{~nm}$ & powder & not available & {$[61]$} \\
\hline $\begin{array}{c}\text { Aspergillius } \\
\text { wentii }\end{array}$ & magnetite & $46.50 \mathrm{~nm}$ & powder & not available & {$[61]$} \\
\hline Alcaligenes faecalis & $\begin{array}{l}\text { Ferrous sulfate } \\
\qquad\left(\mathrm{FeSO}_{4}\right) \\
\text { magnetite }\end{array}$ & $\begin{array}{l}43.60 \mathrm{~nm}, \\
12.30 \mathrm{~nm}\end{array}$ & powder & not available & {$[61]$} \\
\hline Bacillius coagulans & $\begin{array}{l}\text { Ferrous sulfate } \\
\qquad\left(\mathrm{FeSO}_{4}\right)\end{array}$ & Not detected & powder & not available & {$[61]$} \\
\hline Fussarium oxysporum & Magnetie & $20-50 \mathrm{~nm}$ & Quasi-spherical & extracellular & {$[62]$} \\
\hline Verticillium sp. & Magnetite & $10-40 \mathrm{~nm}$ & Cubic & extracellular & {$[62]$} \\
\hline $\begin{array}{l}\text { Klebsiella } \\
\text { oxytoca }\end{array}$ & $\begin{array}{l}\text { Ferrihydrite, } \\
\text { magnetite }\end{array}$ & Not detected & Not available & extracellular & {$[63]$} \\
\hline
\end{tabular}


Nonetheless, not all the microorganisms are found to be competent for the synthesis of iron-based nanoparticles. Some of the iron-based nanoparticles biologically synthesized using microorganisms are summarized in Table 1.

\section{Properties of iron-based nanoparticles}

It was established that iron-based nanoparticles with appropriate surface chemistry are an effective tool for numerous in vivo applications such as magnetic resonance imaging contrast enhancement, tissue repair, immunoassay, detoxification of biological fluids, hyperthermia and drug delivery, etc [64-66]. The unique properties of nanoparticles are strongly determined by their size and shape [66]. For example, magnetite $\mathrm{Fe}_{3} \mathrm{O}_{4}$ has attracted attention because bulk $\mathrm{Fe}_{3} \mathrm{O}_{4}$ has a high Curie temperature $\left(\mathrm{T}_{\mathrm{c}} \sim 850 \mathrm{~K}\right)$ and nearly a full spin polarization at room temperature, both properties of great potential for applications in giant magneto-electronic and spin-valve devices based on magnetic films [68].

Nanoparticles of iron oxide such as maghemite, $\gamma-\mathrm{Fe}_{2} \mathrm{O}_{3}$, magnetite, $\mathrm{Fe}_{3} \mathrm{O}_{4}$ and haematite, $\alpha-\mathrm{Fe}_{2} \mathrm{O}_{3}$, have been thoroughly investigated for their potential applications in the field of biomedical engineering. Among afore mentioned iron oxides, magnetite has proven to be the most promising for this particular field of applications $[69,70]$. Biomedical applications require particles of a nanometric scale [70]. This requirement is explained by the fact that the size of nanoparticles is similar to that of most biological molecules and structures making them good candidates for application in both in vivo and in vitro biomedical research [71].

In addition to the specific structural characteristics, biomedical applications require non-toxic and biocompatible iron nanoparticles. Several studies [72] conducted on the cytotoxicity of iron nanoparticles have not indicated any membrane permeability alterations and low cytotoxicity of nanoparticles in vitro and in vivo. The cytotoxicity was due to the material chemistry. Therefore an important factor which may influence their possible applications is the chosen route for their synthesis. At this point, production of nanoparticles using microorganism seems to be the most suitable route of synthesis.

\section{Applications \\ Industrial applications}

Iron nanoparticles are successfully implemented in a broad spectrum of applications from magnetic recording to biomedical applications. Each potential application of these nanoparticles requires different properties and different coating agents. For example in data storage applications, the ferromagnetic and antiferromagnetic properties of nanostructured components influence the recording medium capacity. The exchange coupling can supply the extra anisotropy which is needed for magnetization stabilization, thus generating magnetically stable particles [73,74]. Other industrial application of iron-based nanoparticles includes their use as Fenton-like catalyst for the degradation of aqueous organic solutes [75-77].

Iron based catalyst such as magnetite and hematite have been widely used in various industrial productions, including the synthesis of $\mathrm{NH}_{3}$ (the Haber process), the desulfurization of natural gas, dehydrogenation of ethylbenzene to styrene, the Fischer-Tropsch synthesis for hydrocarbons, the oxidation of alcohols, and the large scale manufacture of butadiene [78]

\section{Biomedical applications}

Iron containing nanoparticles offer some attractive possibilities in biomedicine and biological research. Their applications include targeted cancer therapy, hyperthermia, drug carrier, DNA analysis, antibacterial agent, biosensor, cells separation, magnetic resonance imaging (MRI) [79].

\section{Hyperthermia}

Targeted therapy for cancer has attracted great attention from researchers. The concept of hyperthermia consists of cancer treatment by heating the tumor. For this purpose iron oxide nanoparticles are used, as they are efficient heat mediators and at the same time they are drug carriers [80,81]. Heating effect is induced by magnetic nanoparticles (localized within a tumor) under the influence of an oscillating magnetic field. Using this effect once the temperature at the localized region reaches $40-50^{\circ} \mathrm{C}$, cancerous cells will be destroyed without causing extensive damage to healthy tissue (cancerous cells are more sensitive to heat than normal cells) [82-84].

Drug delivery

Drug delivery systems are developed to enable drugs to reach targeted organs allowing a fast preconcentration of drugs in target area and diminish their side effects. Targeted nano-carriers must navigate through blood-tissue barriers to reach targeted cells. They must have a small size so that these particles bypass the blood-brain barrier and the tight epithelial junction of the skin that normally impede delivery of drugs to the desired targeted site. Magnetic drug delivery system uses magnetic carriers that can be loaded with the drugs and directed toward a desired zone, such as tumor cells or blood clots by means of a magnetic field gradient [85]. Even though this method seems to be ideal for specific diseases treatment, there are few requirements which must be fulfilled. It should be taken into account the fluid flow rate, strength 
of the applied magnetic field, the content of magnetic nanoparticles, distribution of the magnetic nanoparticles and concentration of the injected drug [86-88].

\section{MRI imaging}

Functionalized iron nanoparticles have been successfully implemented in the diagnostics due to the possibility to guide them using an external magnetic field $[89,90]$. Magnetic resonance imaging (MRI) is one of the best imaging technique which is used to visualize detailed internal structure in the body and is safe to patients. The basic principle of MRI technique is based on the counterbalance between the small magnetic moment on a proton and the large number of protons present in biological tissue. Resulting effect is measured in the presence of large magnetic field [91]. MRI requires magnetic resonance agents to provide the contrast between the targeted cells and the healthy cells in the body [91-93]. Currently, MRI technique is limited by the properties of iron nanoparticles, improving their properties would help to improve this technique.

\section{Conclusions}

Iron nanoparticles can be produced using microorganisms. These methods offer promising alternatives to the traditional techniques which are commonly used to produce these particles. The development of biogenic methods for iron nanoparticles synthesis is of considerable importance to expand their biotechnological applications, as these methods provide clean, nontoxic nanoscaled particles. However, in order to improve efficiency of the nanoparticles synthesis using microorganisms it is necessary to gather a complete knowledge of the molecular mechanism involved in this procedure. With further studies it may be possible to produce the material at large scales for commercial availability using environmentally benign routes.

\section{References}

[1] Cornell, M. and Schwertmann, U. The Iron Oxides: Structure, Properties, Reactions, Occurrences and Uses. Wiley-VCH GmbH \& Co. KGaA, Weinheim, 2003.

[2] Farrell, D.; Cheng, Y.; McCallum, R.W.; Sachan, M. and Majetich, S.A. Magnetic interactions of iron nanoparticles in arrays and dilute dispersions. Journal of Physical Chemistry B., 2005, 109(28), pp. 13409-13419.

[3] Jain, T.P.; Richey, J.; Strand,M.; Leslie-Pelecky,D.L.; Flask,C. and Labhasetwar, V. Magnetic Nanoparticles with Dual Functional Properties: Drug Delivery and Magnetic Resonance Imaging. Biomaterials, 2008, 29(29), pp. 4012-4021.

[4] Maeda, M.; Kuroda, C.S.; Shimura, T.; Tada, M.; Abe, M.; Yamamuro, S.; Sumiyama, K. and Handa, H. Magnetic carriers of iron nanoparticles coated with a functional polymer for high throughput bioscreening. Journal of Applied Physics, 2006, 99, 08H103.

[5] Khurshid, H.; Tzitzios, V.; Colak, L.; Fang, F. and Hadjipanayis, G.C. Metallic Iron-Based Nanoparticles for Biomedical Applications. Journal of Physics: Conference Series, 2010, 200, 072049.

[6] Bendrea, A.-D.; Catargiu, A.-M.; Grigoras, M.; Hybrid organic-inorganic composite materials for application in chemical sensors. Chemistry Journal of Moldova. General, Industrial and Ecological Chemistry, 2009, 4(2), pp.100-104.

[7] Akhmedov, F.I.; Asadova, A.Z.; Guseynova, M.E.; Kuliyev, A.D. The study of conductivity of the macrosystem dielectric polypropylene (PP) - semiconductor $\alpha-\left(\mathrm{Fe}_{2} \mathrm{O}_{3}\right)$. Surface Engineering and Applied Electrochemistry. Electrical Precision Treatment of Materials, 2011, 47(5), pp. 15-17, (Rus.).

[8] Lacroix, L.-M.; Lachaize, S.; Falqui, A.; Blon, T.; Carrey, J. and Respaud, M. Ultrasmall iron nanoparticles: Effect of size reduction on anisotropy and magnetization. Journal of Applied Physics, 2008, 103, 07 D521.

[9] Anghel, L.; Balasoiu, M.; Ishchenko, L.A.; Stolyar, S.V.; Rogachev, A.V.; Kurkin, T.S.; Kuklin, A.I.; Raikher, Yu.L.; Iskhakov, R.S.; Arzumanian, G.M. SAXS studies of ultrasonicated dispersions of biomineral particles produced by Klebsiella oxytoca. Solid State Phenomena, 2012, Vol. 190, pp. 621-624.

[10] Anghel, L.; Balasoiu, M.; Ishchenko, L.A.; Stolyar, S.V.; Kurkin, T.S.; Rogachev A.V.; Kuklin, A.I.; Kovalev, Yu.S.; Raikher, Yu.L.; Iskhakov, R.S.; Duca, Gh. Characterization of bio-synthesized nanoparticles produced by Klebsiella oxytoca. Journal of Physics: Conference Series, 2012, 351, 012005, pp. 1-7.

[11] Huang, K.-C.; Chou, K.-S. Microstructure changes to iron nanoparticles during discharge/charge cycles. Electrochemistry Communications, 2007, 9, pp. 1907-1912.

[12] Wu, W.; He, Q. and Jinag, C. Magnetic Iron Oxide Nanoparticles: Synthesis and Surface Functionalization Strategies. Nanoscale Research Letters, 2008, 3, pp. 397-415.

[13] Gubin, S.P.; Kosharov, Yu.A.; Khomutov, G.B. and Yurkov, G.Yu. Magnetic nanoparticles: preparation, structure and properties. Russian Chemical Reviews, 2005, 74(6), pp. 489-520.

[14] Schmidt, H.; Nanoparticles by chemical synthesis, processing to materials and innovative applications. Applied Organometallic Chemistry, 2001, 15, pp. 331-343.

[15] Kura, H.; Takahashi, M. and Ogawa, T. Synthesis of Monodisperse Iron Nanoparticles with a High Saturation 
Magnetization Using an $\mathrm{Fe}(\mathrm{CO})_{\mathrm{x}}$ Oleylamine Reacted Precursor. Journal of Physical Chemistry C, 2010, 114, pp. 5835-5838.

[16] Liu, J.; Sun, Z.; Deng, Y.; Zou, Y.; Li, C.; Guo, X.; Xiong, L.; Gao, Y.; Li, F. and Zhao, D. HighlyWater-Dispersible Biocompatible Magnetite Particles with Low Cytotoxicity Stabilized by Citrate Groups. Angewandte Chemie International Edition, 2009, 48, pp. 5875-5879.

[17] Sipavičius, Č.; Mažeika, K.; Padgurskas, J.; Vaitiekūnas, P.; Žunda, A. Generation of ferromagnetic micro- and nanoparticles by laser and mechanical milling methods. Surface Engineering and Applied Electrochemistry. Electrical Precision Treatment of Materials, 2011, 47(3), pp. 10-14.

[18] Jankauskas, V.; Padgurskas, J.; Žunda, A.; Prosyčevas, I. Research into nanoparticles obtained by electric explosion of conductive materials. Surface Engineering and Applied Electrochemistry. Electrical Processes in Engineering and Chemistry, 2011, 47(2), pp. 79-85.

[19] Mohapatra, M. and Anand, S. Synthesis and applications of nano-structured iron oxides/hydroxides - a review. International Journal of Engineering, Science and Technology, 2010, 2(8), pp. 127-146

[20] Kannan, N. and Subbalaxmi, S. Biogenesis of nanoparticles - A current perspective. Reviews on Advanced Material Science, 2011, 27, pp. 99-114.

[21] Li, X.; Xu, H.; Chen, Z.-S. and Chen, G. Biosynthesis of Nanoparticles by Microorganisms and Their Applications. Journal of Nanomaterials, 2011, Article ID 270974.

[22] Carvallo, C.; Sainctavit, P.; Arriero, M.-A.; Menguy, N.; Wang, Y., Ona-Nguema, G. and Brice-Profeta, S. Biogenic vs. abiogenic magnetite nanoparticles: A XMCD study. American Mineralogist, 2008, 93, pp. 880-885.

[23] Battacharya, R. and Mekherjee, P. Biological properties of "naked" metal nanoparticles. Advanced Drug Delivery Review, 2008, 60(11), pp. 1289-1306.

[24] Albrecht, M.; Janke, V.; Sievers, S.; Siegner, U.; Schüler, D. and Heyen, U. Scanning force microscopy study of biogenic nanoparticles for medical applications. Journal of Magnetism and Magnetic Materials, 2005, pp. 290291.

[25] Abhilash, K.R. and Pandey, B.D. Microbial synthesis of iron-based nanomaterials - A review. Bulletin of Materials Science, 2011, 34(2), pp. 191-198.

[26] Faivre, D. and Schüler, D. Magnetotactic Bacteria and Magnetosomes. Chemical Reviews, 2008, 108, pp. 48754898.

[27] Roh, Y.; Vali, H.; Phelps, T.J. and Moon, J.-W. Extracellular Synthesis of Magnetite and Metal-Substituted Magnetite Nanoparticles. Journal of Nanoscience and Nanotechnology, 2006, 6, pp. 3517-3520.

[28] Sundaram, P.A; Augustine, R. and Kannan, M. Extracellular Biosynthesis of Iron Oxide Nanoparticles by Bacillus subtilis Strains Isolated from Rhizosphere Soil. Biotechnology and Bioprocess Engineering, 2012, 17, pp. 835840.

[29] Duca, Gh. Homogeneous Catalysis with Metal Complexes: Fundamentals and Applications. Springer Series in Chemical Physics: Berlin; Heidelberg, 2012, XII, 478 p.

[30] Yeoung-Sang, Y. Characterization of Functional Groups of Protonated Sargassum polycystum Biomass Capable of Binding Protons and Metal Ions. Journal of Microbiology and Biotechnology, 2004, 14(1), pp. 29-34.

[31] Wilke, A.; Buchholz, R. and Bunke, G. Selective biosorption of heavy metals by algae. Environmental Biotechnology, 2006, 2(2), pp. 47-56

[32] Das, K. and Thiagarajan, P. Mycobiosynthesis of Metal Nanoparticles. International Journal of Nanotechnology and Nanoscience, 2012, 1, pp. 1-10.

[33] Zinicovscaia, I.; Duca, Gh.; Rudic, V.; Cepoi, L.; Chiriac, T.; Frontasyeva, M.V.; Pavlov, S.S.; Gundorina, S.F. Spirulina platensis as biosorbent of zinc in water. Environmental Engineering and Management Journal, 2013, 12(5), pp. 1079-1084.

[34] Wase, J. and Forster, C. Biosorbents for Metal Ions. Taylor and Francis Ltd, Gunpowder Square, London, England, 1997.

[35] Ahalya, N.; Ramachandra, T.V. and Kanamadi, R.D. Biosorption of Heavy Metals. Research Journal of Chemistry and Environment, 2003, 7(4), pp. 71-79.

[36] Benderliev, K. Algae and Cyanobacteria Release Organic Chelators in the Presence of Inorganic Fe(III) thus Keeping Iron Dissolved. Bulgarian Journal of Plant Physiology, 1999, 25(1-2), pp. 65-75.

[37] Singh, C.; Sharma, V.; Naik, Kr. P.; Khandelwal, V.; Singh, H. A Green Biogenic Approach for Synthesis of Gold and Silver Nanoparticles Using Zingiber Officinale. Digest Journal of Nanomaterials and Biostructures, 2011, 6(2), pp. 535-542.

[38] Sag, Y. and Kutsal, T. Recent Trends in the Biosorption of Heavy Metals: A Review. Biotechnology and Bioprocess Engineering, 2001, 6, pp. 376-385.

[39] Volesky, B. and Holan, Z.R. Biosorption of Heavy Metals, Biotechnology Progress, 1995, 11, pp. 235-250.

[40] Kratochvil, D.; Pimentel, P. and Volesky, B. Removal of Trivalent and Hexavalent Chromium by Seaweed Biosorbent. Environmental Science and Technology, 1998, 32, pp. 2693-2698. 
[41] Yang, J. and Volesky, B. Modeling Uranium - Proton Ion Exchange in Biosorption. Environmental Science and Technology, 1999, 33, pp. 4079-4085.

[42] Schiewer, S. and Wong, M.H. Ionic Strength Effects in Biosorption of Metals by Marine Algae. Chemosphere, 2001, 41, pp. 271-282.

[43] Waldron, K.J.; Rutherford, J.C.; Ford, D.; Robinson, N.J. Metalloproteins and metal sensing. Nature, 2009, 460, pp. 823-830.

[44] Paz, Y.; Katz, A.; Pick, U. A Multicopper Ferroxidase Involved in Iron Binding to Transferrins in Dunaliella salina Plasma Membranes. The Journal of Biological Chemistry, 2007, 282(12), pp. 8658-8666.

[45] Protein Data Bank - an information portal to biological macromolecules http://www.rcsb.org/pdb/home/home.do

[46] Taylor, A.B.; Stoj, C.S.; Ziegler, L.; Kosman, D.J.; Hart, P.J. Crystal Structure of Fet3p, a Multicopper Oxidase that Functions in Iron Import. Proceedings of the National Academy of Science USA, 2005, 106, pp. 1545915464.

[47] Yang, N.; Zhang, H.; Wang, M.; Hao, Q.; Sun, H. Iron and bismuth bound human serum transferrin reveals a partially-opened conformation in the N-lobe. Scientific Reports, 2012, 2, doi:10.1038/srep00999.

[48] Sun, X.L.; Baker, H.M.; Shewry, S.C.; Jameson, G.B.; Baker, E.N. Structure of recombinant human lactoferrin expressed in Aspergillus awamori. Acta Crystallographica Section D, 1999, 55, pp. 403-407.

[49] Crichton, R. Inorganic Biochemistry of Iron Metabolism: From Molecular Mechanisms to Clinical Consequences. 2nd ed, John Wiley\&Sons, Chichester, England, 2001.

[50] Chasteen, D.N. and Harrison, P. Mineralization in Ferritin: An Efficient Means of Iron Storage. Journal of Structural Biology, 1999, 126, pp. 182-194.

[51] Humphrey, W.; Dalke, A. and Schülten, K. VMD - Visual Molecular Dynamics, Journal of Molecular Graphics, 1996, 14, pp. 33-38.

[52] Amemiya, Y.; Arakaki, A.; Staniland, S.S.; Tanaka, T.; Matsunaga, T Controlled formation of magnetite crystal by partial oxidation of ferrous hydroxide in the presence of recombinant magnetotactic bacterial protein Mms6. Biomaterials, 2007, 28, pp. 5381-5389.

[53] Bazylinski, D.A.; Frankel, R.B.; Heywood, B.R.; Mann, S.; King, J.W.; Donaghay, P.L.; Hanson, A.K. Controlled Biomineralization of Magnetite $\left(\mathrm{Fe}_{3} \mathrm{O}_{4}\right)$ and Greigite $\left(\mathrm{Fe}_{3} \mathrm{~S}_{4}\right)$ in a Magnetotactic Bacterium. Applied and Environmental Microbiology, 1995, 61(9), pp. 3232-3239.

[54] He, W.; Zhou, W.; Wang, Y., Zhang, X.; Zhao, H.; Zhao, H.; Li, Z.; Yan, S. Biomineralization of iron phosphate nanoparticles in yeast cells. Material Science and Engineering C, 2009, 29, pp. 1348-1350

[55] Lefevre, Ch.T.; Abreu, F.; Lins, U.; Bazylinski, D.A. Nonmagnetotactic Multicellular Prokaryotes from LowSaline, Nonmarine Aquatic Environments and Their Unusual Negative Phototactic Behavior. Applied and Environmental Microbiology, 2010, 76(10), pp.3220-3227.

[56] Mahdavi, M.; Namvar, F.; Bin Ahmad, M.; Mohamad, R. Green Biosynthesis and Characterization of Magnetic Iron Oxide $\left(\mathrm{Fe}_{3} \mathrm{O}_{4}\right)$ Nanoparticles Using Seaweed (Sargassum muticum) Aqueous Extract. Molecules, 2013, 18, pp. 5954-5964.

[57] Miot, J.; Benzerar, K.; Morin, G.; Andreas, K.; Bernard, S.; Obst, M.; Ferard, C.; Skouri-Panet, F.; Guigner, J.M.; Posth, N.; Galvez, M.; Brown Jr., G.E.; Guyot, F. Iron biomineralization by anaerobic neutrophilic iron-oxidizing bacteria. Geochimica et Cosmochimica Acta, 2009, 73, pp. 696-711.

[58] Perez-Gonzales, T.; Jimenez-Lopez, C.; Neal, A.L.; Rull-Perez, F.; Rodriguez-Navarro, A.; Fernandez-Vivas, A.; Ianez-Pareja, E. Magnetite biomineralization induced by Shewanella oneidensis. Geochemica et Cormochemica Acta, 2010, 74, pp. 967-979.

[59] Posfai, M.; Moskowitz, B.M.; Arato, B.; Schüler, D.; Flies, Ch.; Bazylinski, D.A.; Frankel, R.B. Properties of intracellular magnetite crystals produced by Desulfovibrio magneticus strain RS-1. Earth and Planetary Science Letters, 2006, 249, pp. 444-455.

[60] Zhu, K.; Pan, H.; Li, J.; Yu-Zhang, K.; Zhang, S.D.; Zhang, W.Y.; Zhou, K.; Yue, H.; Pan, Y.; Xiao, T.; Wu, L.F. Isolation and characterization of a marine magnetotactic spirillum axenic culture QH-2 from an intertidal zone of the China Sea. Research in Microbiology, 2010, 161, pp. 276-283.

[61] Kaul, R.K.; Kumar, P.; Burman, U.; Joshi, P.; Agrawal, A.; Raliya, R.; Tarafdar, J.C. Magnesium and iron nanoparticles production using microorganisms and various salts. Material Science-Poland, 2012, 30(3), pp. 254-258.

[62] Bharde, A.; Rautaray, D.; Bansal, V.; Ahmad, A.; Sarkar, I.; Yusuf, M.S.; Sanyal M.; Sastry, M. Extracellular Biosynthesis of Magnetite using Fungi. Small, Wiley InterScience, 2006, 2(1), pp. 135-141.

[63] Arčon, I.; Piccolo, O.; Pagnelli, S.; Baldi, F. XAS analysis of a nanostructured iron polysaccharide produced anaerobically by a strain of Klebsiella oxytoca. Biometals, 2012, DOI 10.1007/s10534-012-9554-6.

[64] Boisseau, P. and Loubaton, B. Nanomedicine, Nanotechnology in medicine. Comptes Rendus de L'Academie des Science, 2011, hal-00598930. 
[65] Frankel, B.R. Biological Permanent Magnets. Hyperfine Interactions, 2003, 151/152, pp. 145-153

[66] Gupta, A.K. and Gupta, M. Cytotoxicity Suppression and Cellular Uptake Enhancement of Surface Modified Magnetic Nanoparticles, Biomaterials, 2004, doi:10.1016/j.biomaterials.2004.05.022.

[67] Rai, M. and Duran, N. Metal Nanoparticles in Microbiology. Springer-Verlag, Berlin, Heidelberg, 2011

[68] Goya, G.F.; Bersquo, T.S.; Fonseca, F.C. and Morales, M.P. Static and Magnetic Properties of Spherical Magnetite Nanoparticles. Journal of Applied Physics, 2003, 94(5), pp. 3520-3528.

[69] Lodhia, J.; Mandarano, G.; Ferris, N.J., Eu, P.; Cowell, S.F. Development and use of iron oxide nanoparticles (Part 1): Synthesis of iron oxide nanoparticles for MRI. Biomedical Imaging and Intervention Journal, 2010, 6(2), doi: 10.2349/biij.6.2.e12.

[70] Gupta, A.K. and Gupta, M. Synthesis and Surface Engineering of Iron Oxide Nanoparticles for Biomedical Applications. Biomaterials, 2005, 26(18), pp. 3995-4021.

[71] Mendez-Vilas, A. Science against Microbial Pathogens: Communicating current research and technological advances. Volume 1, Formatex Research Center, 2011.

[72] Yang, Z., Liu, Z.W.; Allaker, R.P.; Reip, P.; Oxford, J.; Ahmad, Z. and Ren, G. Review of Nanoparticles Functionality and Toxicity on the Central Nervous System. Journal of the Royal Society Interface, 2010, doi:10.1098/rsif.2010.0158.focus.

[73] Lu, A.-.H.; Salabas, E.L. and Schüth, F. Magnetic Nanoparticles: Synthesis, Protection, Functionalization, and Application. Angewandte Chemie, 2007, 46, pp. 1222-1244.

[74] Zhang, X.X.; Wen, G.H.; Huang, S.; Dai, L.; Gao, R.; Wang, Z.L. Magnetic Properties of Fe Nanoparticles Trapped at the Tips of the Aligned Carbon nanotubes. Journal of Magnetism and Magnetic Materials, 2001, 231, L9-L12.

[75] Shahwan, T.; Abu Sirriah, S.; Nairat, M.; Boyaci, E.; Eroglu, A.E.; Scott, T.B.; Hallam, K.R. Green synthesis ofiron nanoparticles and their application as a Fenton-like catalyst for the degradation of aqueous cationic and anionic dyes. Chemical Engineering Journal, 2011, 172, pp. 258-266.

[76] Shin, S.; Yoon, H.; Jang, J. Polymer-encapsulated iron oxide nanoparticles as highly efficient Fenton catalysts. Catalysis Communications, 2008, 10, pp. 178-182.

[77] Xu, L.; Wang, J. A heterogeneous Fenton-like system with nanoparticulate zero-valent iron for removal of 4-chloro-3-methyl phenol, Journal of Hazardous Materials, 2011, 186, pp. 256-264.

[78] Faraji, M.; Yamini, Y.; Rezaee, M. Magnetic Nanoparticles: Synthesis, Stabilization, Functionalization, Characterization, and Applictaions. Journal of the Iranian Chemical Society, 7(1), 2010, pp. 1-37.

[79] Berry, C.C.; Curtis, A.S.G. Functionalisation of Magnetic Nanoparticles for Applications in Biomedicine. Journal of Physics D: Applied Physics, 2003, 36, pp. R198-R206.

[80] Yang, C.; Rait, A.; Pirollo, K.F.; Dagata, J.A.; Farkas, N.; Chang, E.H. Nanoimmunoliposome Delivery of Superparamagnetic Iron Oxide Markedly Enhances Targeting and Uptake in Human Cancer Cells In Vitro and In Vivo. Nanomedicine, 2008, 4(4), pp. 318-329.

[81] Byrne, J.M.; Coker, V.S.; Moiser, S.; Wincott, P.L.; Vaughan, D.J.; Tuna, F.; Arenholz, E.; van der Laan, G.; Pattrick, R.A.D.; Lloyd, J.R.; Telling, N.D. Controlled Cobalt Doping in Biogenic Magnetite Nanoparticles. Journal of the Royal Society: Interface, 2013, 10, 20130134.

[82] Miaskowski, A. and Krawczyk, A. Magnetic Fluid Hyperthermia for Cancer Therapy. Przeglad Elekrotechniczny (Elecrical Review), 2011, ISSN 0033-2097, R. 87, NR 12b, pp. 125-127.

[83] Cherukuri, P.; Glazer, E.S.; Curley, S.A. Targeted Hyperthermia Using Metal Nanoparticles. Advanced Drug Delivery Reviews, 2010, 62, pp. 339-345.

[84] Fortin, J.-P.; Wihlem, C.; Servais, J.; Menager, C.; Bacri, J.-P. and Gazeau, F. Size-Sorted Anionic Iron Oxide Nanomagnets as Colloidal Mediators for Magnetic Hyperthermia, Journal f American Chemical Society, 2007, 129, pp. 2628-2635.

[85] Lee, J.W. and Foote, R.S. Micro and Nano Technologys in Bioanalysis, Methods in Molecular Biology, Vol. 544, Human Press, 2009.

[86] Viroonchatapan, E.; Ueno, M.; Sato, H.; Adachi, I.; Nagae, H.; Tazawa, K. and Horikoshi, I. Preparation and Characterization of Dextran Magnetite-Incorporated Thermosensitive Liposmes: An on-line Flow System for Quantifying Magnetic Responsiveness. Pharmaceutical Research, 1995, 12(8), pp. 1176-1183.

[87] Kiwada, H.; Sato, J.; Yamada, S. and Kato, Y. Feasibility of Magnetic Liposomes as a Targeting Device for Drugs. Chemical Pharmaceutical Bulletin, 1986, 34(10), pp. 4253-4258.

[88] Akhtar, J.; Chaturvedi, R.; Sharma, J.; Mittal, D.; Pardhan, P. Magnetized carrier as novel drug delivery system. International Journal of Drug Delivery Technology, 2009, 1(1), pp. 28-35.

[89] Shubayev, V.I.; Pisanic, T.R., Jin, S. Magnetic Nanoparticles for Theragnostics. Advanced Drug Delivery Reviews, 2009, 61, 467-477.

[90] Pankhurst, Q.A.; Connolly, J.; Jones, S.K..; and Dobson, J. Applications of Magnetic Nanoparticles in Biomedicine. Journal of Physics D: Applied Physics, 2003, 36, pp. R167-R181. 
[91] Hwang, Y. H. and Lee, D.Y. Magnetic Resonance Imaging using Heparin-Coated Superparamagnetic Iron Oxide Nanoparticles for Cell Tracking in vivo. Quantitative Imaging in Medicine and Surgery, 2012, doi: 10.3978/j. issn.2223-4292.2012.06.03.

[92] Hadjipanayis, C.G.; Bonder, M.J.; Balakrishnan, S.; Wang, X.; Mao, H. Hadjipanayis, G.C., Metallic Iron Nanoparticles for MRI Contrast Enhancement and Local Hyperthermia. Small, 2008, 4(11), pp. 1925-1929.

[93] Arbab, A.S.; Bashaw, L.A.; Miller, B.R.; Jordan, E.K.; Lewis, B.K.; Kalish, H. and Frank, J.A. Characterization of Biophysical and Metabolic Properties of Cells Labeled with Superparamagnetic Iron Oxide Nanoparticles and Transfection Agent for Cellular MR Imaging. Radiology: MR Imaging of Superparamagnetic Iron Oxide-labeled Cells, 2003, 229(3), pp. 838-846. 